\title{
Politics of Education
}

Tim Kajian PSP2M

\begin{abstract}
This article aims to dissect education political thinking in Indonesia regarding policies built for the advancement and Development of Indonesian community education quality. The educational policy that is still flavoured with capitalist and structuralist makes the pattern of education only produce human mapping in certain groups and strata of science. The approach used in this writing is literature research, with a data analysis technique in the form of content analysis with the aim of obtaining valid inference and can be re-examined based on its context. In the results of the study of education policy in Indonesia, there are several objectification for the changes in the strata policy to find their own identity as an institution that produces human resources. The need to change the centrality of educational patterns with generalities based on human resource capabilities and infrastructure availability. Using patterns of active theory, a view that emphasizes the observation of educational inputs collectively where the most important angle to be considered by the educational policymakers is the process of personal maturity of the students who must be facilitated, of their needs and be guided towards maturity.
\end{abstract}

Keywords: educational, pruralism, political, movement, policy

\section{INTRODUCTION}

Education as a pillar of the nation is our predecessor's ideals since the country was founded by the heroes, the struggle to achieve independence does not begin with an eruption of firearms as it was constructed through films Historical, but rather independence begins with education. We call it, Kartini, Cokroaminoto, Ki Hajar Dewantara and others. They are a milestone of independence that is able to inspire struggle for the Indonesian nation[1]. Through history we can prove that education is the main weapon to seize independence, because through education people begin to think, plan and people will strive to reach his goal, through the provision that is in his mind, because education is able to awaken one's awareness to see his life that happened then.

Education is an important instrument in building the nation character building[2]. Consciously or not, education is also a longterm investment of the nations in order to move better towards a civilized life. Ibn Khaldun said[3]; "Only in the reality of people who have awareness of the importance of the development of science and education, then civilization and the value of constructive cultural values will be enforced".

In this context, education is not only interpreted as transfer of shaering alone, but more fundamental is that education is a locomotive and dynamicator in the change of society and nation[4]. The development of education should be in the direction of the development of the country's life, the education will become the nadir of the growth of a civilization, we can learn from Japan, Germany and even with Vietnam though. That education became their earliest growing up from the downturn that happened before[5] Conversely our nation who too think industrialized to forget to strengthen the foundation of the structure of development whose name is education.

\section{LITERATURE REVIEW}

Indonesian national Education Historism is the result and influence of ethical politics, where ethical political influence in the field of teaching and education is instrumental in the development and expansion of the world of education and teaching in the Dutch East Indies[6]. One of the most highly qualified ethical groups in this field is Mr. J.H. Abendanon (1852-1925) who was Minister of Culture, religion, and crafts for five years (1900-1905). Since 1900 it is a school, both for the priyayi and the ordinary people who are almost evenly in the areas.

Meanwhile, in society there has been some kind of mental exchange between the Dutch people and indigenous people. Ethical political supporters feel concerned about the indigenous people who are gaining socio-cultural discrimination[7]. To achieve that goal, they sought to realize the natives to break away from feudal fetters and develop themselves according to the western model, which included emancipation processes and demanded education towards self-help.

Continuing what has been achieved before, the government with regulatory authorities continues to strive to protect and develop education, in the opening of the Constitution (Constitution) of the Republic of Indonesia year 1945 stated that one of the purpose of unitary Republic of Indonesia (NKRI) is to educate the life of the nation. In accordance with the opening of the Constitution, the bodies of the Constitutions include article 20, article 21, article 28 C paragraph (1), article 31, and article 32, also mandated that the Government is working on and conducting a national education system and promoting National culture to increase faith and piety to the Almighty God and noble character in order to educate the life of the nation governed by law[8][9]. Education is attempted starting from the human being (actualization) by considering the various possibilities of what is (potentiality), and directed towards the realization of human beings that are supposed to be or human beings (ideality). The purpose of education is nothing but to form human beings who believe and obey God Almighty, noble, healthy, intelligent, Feeling, willed, and able to work; Able to fulfill various needs in a reasonable, personality, societal and cultured.

Implication, education should serve to realize the various potential of human beings in the context of diversity, morality, morality, individuality/personality, sociality and culture, and Integrated. In other words, education serves to humanize the human being[10]. 
In the community, inevitably the quality education must be established by the Government. Education should be an easy-toreach realm for anyone in the Republic. Nonsense if the government aspires to enforce human rights in our country, if education is still a second opinion for the government in issuing policies. Building a country through a friendly education for all is not loss. The community that will be created is a society with the level of mutual respect for each individual rights and increase the attitude of tolerance[11]. Hope about how everyone can feel the education, can get the right of education so it should be that the government has been thinking about the education approach that will be later discussed in the next section.

\section{METHOD}

In this study, researchers used the approach of literature studies. The literature study is a study used to dull information and data with the help of various materials in libraries and the Internet such as documents, books, journals, magazines, historical stories[12]. Meanwhile, according to the literature study experts are theoretical studies, references and other scientific literature related to the culture, values and norms that develop in the social situation studied.

The data analysis technique used in this study is a method of content analysis. This analysis is used to obtain valid inference and can be researched based on its context[13]. In this analysis will be the process of selecting, comparing, combining and sorting various information and data until found the relevant[14].

\section{RESULT}

Thoughts never arise from an empty space. It is not the result of the creatio ex nihilo that seems to be a vacuum from history, from social relations, and if it is present with a rash of excitement. The mind must be seen as an expression of relations between various material preconditions: the socio-political-economic situation, historical configuration and eventual institutions, both in the formal (university)[15] and informal Sense (café, Salon des Artistes)[16].

First we see the University of Paris or what is known as the Sorbonne. The University of Paris was founded in 1200 by King Philippe-Auguste and supported by papal decree by Pope Gregory IX in 1231 which

Includes four faculties: Theology, Law, medicine as the main faculty, and the arts as a low faculty. In 1257, King Louis IX's adviser Robert de Sorbon established a special faculty for the poor theological students of this campus which was later known as the Sorbonne[17]. Because the campus was slowly gaining a strong political position, it was since the 15th century overall of the Paris university known as the Sorbonne. At the time, the theological faculty at the Sorbonne held a strong political role with the right to censor on behalf of the king and the Pope. This political power was so effective that a philosopher of caliber René Descartes[18], when he published his book, regarded as a milestone in the birth of Modern philosophy, meditation on philosophy first, felt the need to' ask for restu' from Dean and The Doctors' sacred Faculty of Theology in Paris' and presented his work to them while begging for patronage[19].

Outside of the ' Sorbonne ' or the University of Paris, there are other educational institutions that are most prestigious among the French intellectuals of philosophy. The institution is none other than the École Normale Supérieure (ENS). This institution is one of a series of 'Great Schools' (Grandes Écoles) emerging from the tradition of the French Revolution (all established at that time), another well-known example of ENS established in the year 1794 in Rue D'ulm by the Minister of Education At that time, Joseph Lakanat, to forge students as teachers who really mastered the study's problems so that they could give the best lesson[20]. The Normaliens (a designation for students studying in the ENS)[21] does not acquire any academic degree and therefore they must also take undergraduate and post-graduate programs on other campuses. Uniquely, although not promising any title, ENS still stands as an elite school with a very high standard and a long line of registrants. Among the prospective students who later became great philosophers, the failed number of the first test was pretty much; Derrida failed his first Test, Foucault was so and even had to repeat the preparatory class (Khâgne) to take the exam, Lyotard failed twice in his exam and eventually opted to the Sorbonne[22]. The number of students received is caused by a very high standard of entrance exams. But the harsh forging in the ENS proved fruitful. This is evident from the fact that the high percentage of teachers in

The Sorbonne from the ENS of the third institution worth mentioning here is the Collège de France which has been established since the year 1530 by King François I. Collège is different from the campus in general because besides he does not provide any degree for the Follow these lectures and do not conduct any exams, the participation is fully open and free of charge. The whole French community can come and attend lectures given in the Collège[23]. The institution is very prestigious for French intellectuals because its members, teachers who are allowed to lecture in the Collège, are specially appointed by the senior and only intellectuals who are deemed to have been completely reach the top of mastery over their chosen fields. Alan Schrift notes that the role of the Collège is mainly cultural, or in other non-academic words[24]. Because the public was composed of all the French communities with diverse backgrounds, then the advantage of being a teacher at the Collège was able to directly influence the landscape of the French culture[25].

\section{Discussion}

The reform of higher education is not detached from the transformation of power from centralization to decentralization marked the process of delegation of authority and responsibility to the district and municipal governments, in a regional and global context, Indonesia is a good example of transforming movement from centralization of power towards decentralization especially in education[26]. 
After the new order, the Government of Indonesia plans to provide greater space to the university in the form of autonomy, especially finance. This was previously fully funded by state finances. This new direction is reflected in the application of several legal regulations (PP Nomor 60 and 61 year 1999, ACT 20/2003 on the National education system).

In HELTS, university autonomy is defined as a decentralized central government authority to institutions. In line with that, Welch also explained that the implementation of the legal entity is a mirror of decentralized education at the university. PTN gained autonomy in many aspects of university management, but they also had to demonstrate their accountability to stakeholders[27]. Autonomous Status should be described as a major university authority to improve financial resources, human resources for university quality improvement. Autonomous universities are an important element of higher education reform results. In the old centralized system, the central government has encouraged curriculum development. The role of the central government has been very strong, even with national standards designed at the central level[28]. The university system adopts a rigid national standard, otherwise it cannot be recognized by the political authorities in this regard the Ministry of Education and Culture.

Comparing two different situations is not easy, maybe every human education will hope that our nation can sample what has happened in France some time ago. But the development of education that occurs there is an evolutionary form of the character of education that began to grow its development is still dominated by the authority of the King of education strata found his own identity as an institution that produce exceptional human resources[29].

The development of education in Indonesia is also a legacy of conservative patterns which at the time only certain classes are able to access the education. Regardless of all, nowadays, the education that while we get is an assessment of what is being constructed by state leaders.

History proves early in the Republic will be formed only feudal people who have more opportunity to reach education, until the new order finally arrived the education still belongs to those who have capital. Try again we understand what happened in the 1600-1700 period in France, the participation is completely open and free of cost, the whole French Community can come and follow the lectures given in the Collège[30]. The school did not even give a degree to his students because the formed was not formal but more on his subsoil when one would understand what he learned. For Indonesia still has a very strong centralist character for the control of the entire education system, we are just a model when the university should accept new students then the size of the collective judgment. The basic rules of SNPTN[31] are referenced to all prospective students who take the admission test, meaning there is a generalization of judgment for each individual who will access the public universities. Therefore, there will be injustice when people who are 12 years studying in Papua must compete for the ration of college with Jakarta[32].

We can imagine people like Derrida, Lyotard, even Foucault should fail to get in on any of the universities in France. The cause is not on the academic inability but the system is forcing them to have competence, about the skills they want to have.

What else do we see about what our colleges produce? With the naked eye we can find the following questions or statements; Then what should I do after graduation?, the parents will always bear the burden of both birth and inner, if my fortune is a lot then I proceed Strata 2, if you do not have it then wait there is a chance of working results,. What can we take from the experience that occurs in France, that our nation still measures education with nominal, we still use the standard number to assess the quality of learners then the value will always be a scourge and the cost will shackle[33].

Using an active theory pattern, a view that emphasizes the observation of educational inputs collectively where the most important angle to observe by the school is the personal maturity process of students to be facilitated, the need to be accepted and guided towards maturity[21]. Therefore, the proportion of school organizations that tend to be mechanistic should be flexible so that its members can create optimal expressions.

\section{CONCLUSION}

In the last part, there are some things that I can conclude, that with the model of education that still put populist rather than subtance, we will always be at a pragmatic level. There are several proposals that we can discuss together related to education and political studies is; It was time the Ministry of Education stood alone without having to participate in the cabinet that is running, this to break the chain of domination of the ruler to the education policy. Secondly, there is an educational regulation that suggests that education is fundamental and is given punishment for

Breach, as well as the assurance of obtaining educational rights for each of the people. There is a special tax modulation that is directed only to education, so for the cost of education will not be politicized by the House of Representatives, and the last is to synchronize between the direction of education development with educational resources.

\section{REFERENCES}

[1] M. C. B. Umanailo, M. Yulisvestra, K. K. Oki, W. Mulyasari, and R. Ridwan, "The Thought of Emile Durkheim in the Contestation of Development in Indonesia," Int. J. Sci. Technol. Res., vol. 8, no. 8, pp. 1881-1885, 2019.

[2] M. C. B. Umanailo, "Integration of Community Empowerment Models [Pengintegrasian Model Pemberdayaan Masyarakat]," Proceeding Community Dev., vol. 2, p. 268, Mar. 2019.

[3] W. Malmia et al., "Problem-Based Learning as an Effort to Improve Student Learning Outcomes," Int. J. Sci. Technol. Res., vol. 8, no. 9, pp. $1140-1143,2019$. 
M. C. B. Umanailo, I. Hamid, M. Nawawi, S. Pulhehe, S. Yusuf, and A. T. Bon, "Utilization of Qualitative Methods in Research Universities," in Proceedings of the International Conference on Industrial Engineering and Operations Management, 2019, pp. $2076-2081$.

[5] M. C. B. Umanailo, "Discourse on the Consumerist Community Consumption," J. Soc. Sci. Res., vol. 5, no. 54, pp. 1181-1186, Apr. 2019.

[6] A. Hasan Afandi and M. C. B. Umanailo, "Watudakon Citizens 'Social Conflict on Joker Toll Road Development in 2017 in Kesamben District, Jombang Regency," J. Soc. Sci. Res., vol. Special Is, no. 5, pp. 656-661, 2018.

[7] M. C. B. Umanailo, "Studi pada Masyarakat Desa Waimangit Kabupaten Buru," SOCA, vol. 12, no. 12, pp. 63-74, 2018.

[8] M. C. B. Umanailo, Sosiologi Hukum, 1st ed. Namlea: FAM PUBLISHING, 2016.

[9] H. Hamiru et al., "Eucalyptus Oil Workers," Int. J. Sci. Technol. Res., vol. 8, no. 9, pp. 1817-1820, 2019.

[10] M. C. B. Umanailo et al., "Comprehension To Village," 2018, pp. 1-2.

[11] B. S. Amanto, M. C. B. Umanailo, R. S. Wulandari, T. Taufik, and S. Susiati, "Local Consumption Diversification," Int. J. Sci. Technol. Res., vol. 8, no. 8, pp. 1865-1869, 2019.

[12] M. C. B. Umanailo, "Teknik praktis grounded theory dalam penelitian kualitatif," 2018, no. April, p. 127.

[13] M. C. B. Umanailo, N. Handayani, A. Masniati, S. H. Makatita, and S. Lisaholit, "The Urbanization and Diversification of Farmland Namlea Village," Int. J. Sci. Technol. Res., vol. 8, no. 8, pp. 1049-1053, 2019.

[14] M. C. B. Umanailo, MASYARAKAT BURU DALAM PERSPEKTIF KONTEMPORER, vol. 53, no. 9. 2015.

[15] S. Rachman, H. Hamiru, M. C. B. Umanailo, Y. Yulismayanti, and H. Harziko, "Semiotic Analysis of Indigenous Fashion in The Island of Buru," Int. J. Sci. Technol. Res., vol. 8, no. 8, pp. 1515-1519, 2019.

[16] M. C. B. Umanailo and T. Yatno, Kajian dan Analisis Sosiologi Dalam Bentuk Kumpulan Essay, Makalah dan Opini. 2015.

[17] M. C. B. Umanailo, MARGINALISASI BURUH TANI AKIBAT ALIH FUNGSI LAHAN, 1st ed. Namlea: FAM PUBLISHING, 2016.

[18] M. C. B. Umanailo, "BUPOLO " Movement. 2019.

[19] M. C. B. Umanailo, "Overview of Phenomenological Research," 2019, pp. 1-6.

[20] M. C. B. Umanailo, ILMU SOSIAL BUDAYA DASAR, 1st ed. Namlea: FAM PUBLISHING, 2015.

[21] M. C. B. Umanailo, MASYARAKAT BURU DALAM PERSPEKTIF KONTEMPORER (Kajian Kritis Perubahan Sosial di Kabupaten Buru), vol. 1. Namlea, 2017.

[22] R. Bugis et al., "Workers in the Namlea Market," Int. J. Sci. Technol. Res., vol. 8, no. 9, pp. 2044-2047, 2019.

[23] M. C. B. Umanailo et al., "Dominance of Economic Capital in Political," in Community Development, Decentralization \& Local Autonomy Politic \& Democracy, Fisip Universitas Brawijaya, 2018, pp. 1-120.

[24] S. Yusuf, M. C. B. Umanailo, R. N. Putri, D. Qhuril, M. Ely, and D. Darma, "Village Institution Relations in the Utilization of Village Funds in Namlea District," Int. J. Sci. Technol. Res., vol. 8, no. 8, pp. 1837-1842, 2019.

[25] L. Rumkel, B. Sam, and M. C. B. Umanailo, "Village Head Partnership, Village Consultative Body and Customary Institution in Village Development," Int. J. Sci. Technol. Res., vol. 8, no. 8, pp. 1058-1063, 2019.

[26] M. C. B. Umanailo, R. Umanailo, R. Bugis, and A. T. Bon, "Empowerment Community in Buru Regency," in Proceedings of the International Conference on Industrial Engineering and Operations Management, 2019, pp. 2070-2075.

[27] M. C. B. Umanailo, "'recycling' consumerism to construction of modern society," no. 1904, 1964.

[28] M. C. B. Umanailo, "Desa Sebagai Poros Pembangunan Daerah,” 2015.

[29] M. C. B. Umanailo, "EKSISTENSI WARANGGANA DALAM RITUAL TAYUB."

[30] M. C. B. Umanailo, "Keterbatasan penggunaan teknologi informasi pada pelayanan dan pembelajaran di universitas iqra buru," 2016.

[31] M. C. B. Umanailo, Marginalisasi Buruh Tani Akibat Alih Fungsi Lahan. 2016.

[32] B. Sam et al., "Female Feminism in the Customary Island of Buru," Int. J. Sci. Technol. Res., vol. 8, no. 8, pp. 1877-1880, 2019.

[33] A. Hasan Afandi and M. C. Basrun Umanailo, "Watudakon Citizens 'Social Conflict on Joker Toll Road Development in 2017 in Kesamben District, Jombang Regency.," J. Soc. Sci. Res., no. Special Issue 5, pp. 656-661, 2018. 